\title{
Mechanical Properties of Silica Fume Modified High-Volume Fly Ash Rubberized Self-Compacting Concrete
}

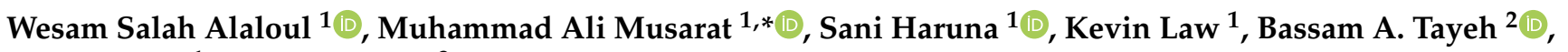 \\ Waqas Rafiq ${ }^{1}$ and Saba Ayub ${ }^{3}$ \\ 1 Department of Civil and Environmental Engineering, Universiti Teknologi PETRONAS, \\ Bandar Seri Iskandar 32610, Malaysia; wesam.alaloul@utp.edu.my (W.S.A.); \\ sani_17000823@utp.edu.my (S.H.); kevinlaw.97.kl@gmail.com (K.L.); waqas_18000277@utp.edu.my (W.R.) \\ 2 Civil Engineering Department, Faculty of Engineering, Islamic University of Gaza, \\ Gaza P.O. Box 108, Palestine; btayeh@iugaza.edu.ps \\ 3 Department of Fundamental and Applied Sciences, Universiti Teknologi PETRONAS, \\ Bandar Seri Iskandar 32610, Malaysia; saba_20000009@utp.edu.my \\ * Correspondence: muhammad_19000316@utp.edu.my
}

Citation: Alaloul, W.S.; Musarat, M.A.; Haruna, S.; Law, K.; Tayeh, B.A.; Rafiq, W.; Ayub, S. Mechanical Properties of Silica Fume Modified High-Volume Fly Ash Rubberized Self-Compacting Concrete. Sustainability 2021, 13, 5571. https:// doi.org/10.3390/su13105571

Academic Editor: Shervin Hashemi

Received: 8 April 2021

Accepted: 13 May 2021

Published: 17 May 2021

Publisher's Note: MDPI stays neutral with regard to jurisdictional claims in published maps and institutional affiliations.

Copyright: (c) 2021 by the authors. Licensee MDPI, Basel, Switzerland. This article is an open access article distributed under the terms and conditions of the Creative Commons Attribution (CC BY) license (https:/ / creativecommons.org/licenses/by/ $4.0 /)$.

\begin{abstract}
The existing form of self-compacting concrete (SCC) comprises of a large amount of powdered and fine materials. In this study, a part of the cementitious material was replaced with constant high-volume fly ash, and a portion of fine aggregates was substituted by crumb rubber (CR). Besides that, silica fume (SF) was added, with the hope that by implementing a new type of nanomaterial, the loss in mechanical strength due to previous modifications such as rubberization and replacement will be prevented. Two variables were found to influence the constituent/component in the mix design: SF and CR. The proportion of SF varies from $0 \%$ to $10 \%$, while that of CR from $0 \%$ to $30 \%$ by volume of the total river sand, where $55 \%$ of cement was replaced by the fly ash. A total of 13 rubberized SCC samples with CR and SF as controlling variables were made, and their design mix was produced by a Design of Experiment (DOE) under the Response Surface Methodology (RSM). The results reveal a slight increase in the mechanical properties with the addition of SF. The theoretical mathematical models and equation for each different mechanical strength were also developed after incorporating the experimental results into the software.
\end{abstract}

Keywords: self-compacting concrete; crumb rubber; strength; silica fume; response surface methodology

\section{Introduction}

The origin of self-compacting concrete (SCC) can be traced back to the year 1986, when Hajime Okamura proposed his idea of having a concrete which is 'alive'. Then, his idea stimulated the development of the prototype of SCC, 2 years later, by Ozawa, to improve the durability of concrete structures [1]. SCC is special in the sense that by just relying on its weight, all process of vibration and compaction during pouring or concreting can be eliminated, by adding superplasticizers into the fresh concrete mixtures [2]. The adding of the superplasticizer is to ensure that the fresh concrete achieves high workability and a decent cohesiveness, so that the fresh concrete can flow and fill even to the narrowest gap between reinforcement bars. A similar level of quality with normal concrete will be produced even without the same degree of compaction. Besides reducing compaction noise, cost, and time in the construction site, the utilization of SCC induces advantages such as constructability, reliability, and low permeability [3-5]. By adding supplementary cementitious materials, the workability of SCC can be stabilized. Moreover, it can aid in reducing the quantity of the cement to be used, and thus help in reducing the environmental carbon footprint related to Portland cement [6-8].

In the past few decades, the waste rubber originated from scrap tyres and rubber products had accumulated to an explicitly large amount, until this issue started threatening 
the environment [9-11]. Approximately 1000 million (M) tyres reach their useful life each year. A vast number of tyres are previously stockpiled or landfilled, either whole or shredded, where the numbers are $3000 \mathrm{M}$ in the EU region and $1000 \mathrm{M}$ in the US alone. Tyres from the vehicle industry are expected to reach $5000 \mathrm{M}$ until 2030, at which point they will be discarded on regular basis [12]. Burning the tyres might seem to be the most convenient and cheapest way. However, the air pollution caused by the emission of hazardous smoke and carbon dioxide $\left(\mathrm{CO}_{2}\right)$ during the open burning process slammed the door shut to this illegal method. Hence, one of the ideologies of recycling scientists and experts is to utilize the waste material as additive in cement-based materials. Crumb rubber (CR) as an additive in concrete is very common nowadays in the field of building materials, as it decreases the stiffness of the concrete [13], improves energy absorption and deformation capacity, and decreases chloride permeability [14,15]. The overall results of these findings show a considerable decline in the stiffness and strength of the concrete after adding CR, mainly due to physical properties and the interaction with aggregates [16-20].

The usage of fly ash to partially replace cement in the total mix is capable of improving the segregation and the strength of concrete [21,22]. Substituting cement with fly ash delivers impactful economic and environmental benefits, as less manufacturing of cement reduces the cost and the carbon footprint to the environment [23-25]. Fly ash also possesses low embodied energy compared to Portland cement. The properties of the cement pastes have a strong influence on the behaviour of the cement-based composites. Thus, controlling the cement hydration products can lead to a greater enhancement, especially in the strength properties of cement pastes.

Studies have shown that the optimal silica fume (SF) addition improves concrete performance $[26,27]$. SF, a by-product of the smelting process in the silicon and ferrosilicon industry, emerged as an attractive alternative that provides a high strength to concrete. The inclusion of SF in concrete gives an early high compressive, tensile, and flexural strength and impacts significantly on the modulus of elasticity, along with increasing the concrete's toughness. Besides that, SF makes the concrete resistive towards chemical attacks. That is why high-performance concrete containing SF is preferable for parking decks, highway bridges, and marine structures [28].

The incorporation of both SF and rubber particles potentially induces a coupling effect on the compressive properties of rubberized concrete. Typical means of enhancing the mechanical properties of concrete or rubberized concrete include mineral additives such as $\mathrm{SF}$, fly ash, and ground granulated blast furnace slag. SF is regarded as a material belonging to the highly pozzolanic category, as the silica content inside exists in a non-crystalline form with a very highly specific surface. The concrete structure bears the interaction of several components, such as aggregates and cement paste. Several researchers [29-31] have stated that the addition of SF to rubberized concrete reduces the adverse impact of the rubber particles and enhances the mechanical properties of the rubberized concrete.

The ideology of incorporating crumb rubber into the cementitious composite comes from the overloading of unhandled rubber waste, which poses a threat to the environment. By introducing the reused crumb rubber, the rubberized concrete mixture is expected to have increased ductility and toughness, higher impact resistance, and improved cracking resistance, as rubber contributes to the enhanced elasticity. Thus, the effect of incorporating silica fume as an additive in the high-volume fly ash rubberized self-compacting concrete was examined to mitigate the loss of mechanical strength due to crumb rubber. This investigation aims to determine the influence of silica fume and crumb rubber on the compressive, tensile, and flexural strength of the rubberized self-compacting concrete with a high volume of fly ash. The addition of silica fume in self-compacting concrete will aid in regaining/mitigating the reduced strength of the rubberized SCC. Due to its fineness and highly reactive properties, it will bridge the inter transition zone between the crumb rubber aggregates and the cement paste, thus improving the strength properties of the rubberized SCC. 
Response surface methodology (RSM) is a way of applying statistical techniques on the interaction between variables and their responses. RSM also entails the design of experiments such that optimized results of the interaction between the variables and between the variables and their responses are developed [32]. Response surface numerical models are also developed to validate the accuracy of the relationship between variables in achieving the desired response. Response surface methodology (RSM) was employed to study the relationship between silica fume and crumb rubber. An analysis of variance (ANOVA) was employed to evaluate the significance of the models developed by the RSM. The rubberized self-compacting concrete was designed in different mix proportions which consist of silica fume, crumb rubber, superplasticizer, cement, coarse aggregates, and river sand. Two variables were found to influence the constituent/component in the mix design: silica fume and crumb rubber. SF varies from $0 \%$ to $10 \%$ by volume, while the proportion of $C R$ varies from $0 \%$ to $30 \%$ by volume of the total fine aggregates, which is the river sand. The idea of incorporating silica fume is to bridge the ITZ gap between the crumb rubber and the cement paste, which may result in the enhancement of the strength properties.

\section{Materials and Methods}

\subsection{Materials}

The materials utilized in the production of rubberized self-compacting concrete consist of Ordinary Portland Cement (OPC), silica fume (SF), fly ash, fine aggregate (F.A), crumb rubber (CR), coarse aggregate (C.A), superplasticizer (SP), and water. The OPC is categorized in Type 1 and met ASTM C1050 specifications. Class C fly ash conforming to the specifications of ASTM C618 was used. River sand with a specific gravity of 2.65 was used for the fine aggregates, and passed through sieve no. 4, whereas the majority of aggregates were retained by sieve no. 200. The crumb rubber (CR) used was obtained from waste tyres, and their size ranged from $600 \mu \mathrm{m}$ to $2.36 \mathrm{~mm}$. The oxide composition of the OPC and fly ash are presented in Table 1 . Natural gravel was used as coarse aggregate with a $20 \mathrm{~mm}$ maximum size and a 2.68 specific gravity. A superplasticizer was added to the mixture in accordance with ASTM C230/C230M-03 to achieve the desired flowability.

Table 1. Oxide composition of OPC and Fly Ash.

\begin{tabular}{ccc}
\hline Oxide (\%) & OPC & Fly Ash \\
\hline $\mathrm{SiO}_{2}$ & 20.76 & 37.8 \\
$\mathrm{Al}_{2} \mathrm{O}_{3}$ & 5.54 & 15.4 \\
$\mathrm{Fe}_{2} \mathrm{O}_{3}$ & 3.35 & 16.5 \\
$\mathrm{MnO}$ & - & 0.33 \\
$\mathrm{CaO}$ & 61.4 & 17.9 \\
$\mathrm{MgO}$ & 2.48 & 2.75 \\
$\mathrm{Na} O$ & 0.19 & 0.26 \\
$\mathrm{~K}_{2} \mathrm{O}$ & 0.78 & 2.85 \\
$\mathrm{TiO}_{2}$ & - & 1.07 \\
$\mathrm{SO}_{3}$ & - & 0.7 \\
Loss on ignition & 2.2 & 1.25 \\
\hline
\end{tabular}

\subsection{Mixing, Casting, and Test Procedure}

The percentage of CR and SF in the modified high volume fly ash rubberized selfcompacting concrete (HVFRSCC) was designed with the aid of a design of experiment (DOE) under the Design Expert software. The percentage of CR ranged from 0\% to 30\%, while that of silica fume (SF) ranged from $0 \%$ to $10 \%$ based on the RSM analysis. A total of 13 runs of combinations with different percentages of CR and SF were developed, as shown in Table 2. CR15SF5, the five duplications, are the central points which the software used to improve the precision of the experiment against any likely errors. Mixing took place in three stages; dry mixing for $2 \mathrm{~min}$, wet mixing for $2 \mathrm{~min}$, adding SP and final mixing for no less than $3 \mathrm{~min}$. Afterwards, the fresh properties of HVFRSCC were determined. 
The fresh mixture of HVFRSCC was then cast into standard moulds of $100 \mathrm{~mm}$ cubes, a $200 \mathrm{~mm} \times 100 \mathrm{~mm}$ cylinder, and a $500 \mathrm{~mm} \times 100 \mathrm{~mm} \times 100 \mathrm{~mm}$ prism. The compressive strength test was performed on hardened cubes of $100 \mathrm{~mm}$. According to BS 12390-3:2009, the loading rate was set at $3.0 \mathrm{kN} / \mathrm{s}$, where the hardened cubes were checked at 7, 14, and 28 days for each combination, in which three specimens were checked for each curing time and procedure, and the average values were reported. The splitting tensile strength of HVFRSCC was measured according to BS EN 12390-6:2009, for every mixture, and assessed at 7, 14, and 28 days of curing. Prisms of $100 \mathrm{~mm} \times 100 \mathrm{~mm} \times 500 \mathrm{~mm}$ were prepared for three points loading bending test as per ASTM C293M-10 [33].

Table 2. Mix Proportions of high-volume fly ash self-compacting concrete (HVFSCC).

\begin{tabular}{lccccccccc}
\hline Mix & CR (\%) & SF (\%) & CR, (kg) & F.A, (kg) & C.A (kg) & $\begin{array}{c}\text { Fly Ash, } \\
(\mathbf{k g})\end{array}$ & $\begin{array}{c}\text { Water, } \\
\mathbf{( k g )}\end{array}$ & $\begin{array}{c}\text { OPC, } \\
(\mathbf{k g})\end{array}$ & $\begin{array}{c}\text { SP } \\
(\mathbf{k g})\end{array}$ \\
\hline CR15SF0 & 15 & 0 & 2.42 & 13 & 15.582 & 5.929 & 3.234 & 4.851 & 0 \\
CR15SF5 & 15 & 5 & 2.42 & 13.70 & 15.582 & 5.929 & 3.234 & 4.609 & 0.24 \\
CR15SF5 & 15 & 5 & 2.42 & 13.70 & 15.582 & 5.929 & 3.234 & 4.609 & 0.24 \\
CR0SF5 & 0 & 5 & 0 & 16.11 & 15.582 & 5.929 & 3.234 & 583 & 0.24 \\
CR15SF10 & 15 & 10 & 2.42 & 13.70 & 15.582 & 5.929 & 3.234 & 4.366 & 0.49 \\
CR15SF5 & 15 & 5 & 2.42 & 13.70 & 15.582 & 5.929 & 3.234 & 4.609 & 0.24 \\
CR15SF5 & 15 & 5 & 2.42 & 13.70 & 15.582 & 5.929 & 3.234 & 4.609 & 0.24 \\
CR30SF10 & 30 & 10 & 4.83 & 11.28 & 15.582 & 5.929 & 3.234 & 4.366 & 0.49 \\
CR15SF5 & 15 & 5 & 2.42 & 13.70 & 15.582 & 5.929 & 3.234 & 4.609 & 0.24 \\
CR30SF5 & 30 & 5 & 4.83 & 11.28 & 15.582 & 5.929 & 3.234 & 4.609 & 0.24 \\
CR0SF0 & 0 & 0 & 0 & 16.11 & 15.582 & 5.929 & 3.234 & 4.851 & 0 \\
CR30SF0 & 30 & 0 & 4.83 & 11.28 & 15.582 & 5.929 & 3.234 & 4.851 & 0 \\
CR0SF10 & 0 & 10 & 0 & 16.11 & 15.582 & 5.929 & 3.234 & 4.366 & 0.49 \\
\hline
\end{tabular}

CR: Crumb rubber, SF: silica fume, C.A: coarse aggregate, F.A: fine aggregate, SP: Superplasticizer.

\section{Results and Discussion}

\subsection{Fresh Properties}

The standard slump test (Flowability) was conducted according to the Specification and Guidelines for SCC, EFNARC 2002. This approach is the most widely used for calculating concrete's self-flow properties. This test chooses the consistency of SCC filling. The concrete is filled in without any concrete spitting, and then the slump funnel is pulled up where the concrete is expected to flow without any of its weight impact. The mixtures with a flow diameter between $600 \mathrm{~mm}$ and $800 \mathrm{~mm}$ were considered in the slump flow test based on the European SCC specifications (EFNARC 2002) [34]. During the mixing phase, slump flow test and $\mathrm{T}_{50}$ time were obtained using the required quantity of fresh HVFRSCC before casting into the moulds as shown in Figure 1. The slump values of HVFRSCC were presented in Figure 2. The slump flow of the HVFRSCC decreases with the percentage increase of CR and SF. It is worth mentioning that all the slump values satisfy the EFNARC 2002 criteria. Besides that, The L-box test was also conducted to identify the passing ability of SCC. The apparatus needed for this test includes a rectangular-section box in the shape of an alphabet ' $\mathrm{L}$ ', with a horizontal and a vertical component, trowel, scoop, and stopwatch which are separated by a movable door. Firstly, the vertical compartment was filled with concrete. Right after filling up, it was set for $1 \mathrm{~min}$, and the door was lifted to let the concrete from the vertical compartment flow into the horizontal compartment. After the flowing is self-halted naturally, the height of the concrete at the end of the horizontal compartment was measured as $\mathrm{H} 2$, a proportion of that remaining in the vertical compartment and in the vertical section, $\mathrm{H} 1$. The blocking ratio, $\mathrm{H} 2 / \mathrm{H} 1$, for this passing test should be 0.80 to 1.00 . If the concrete being tested is truly self-levelling, like water, the value of the blocking ratio will be the same as that of water, which is 1 . It will somehow form a slope of concrete when at rest. The result indicates the SCC's passing ability where the ratio of 0.76 was achieved, where the passage of concrete is restricted by the bars. 


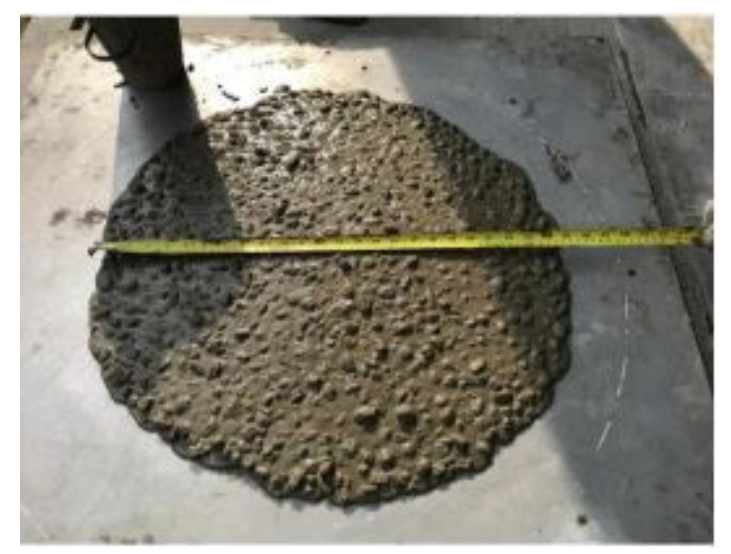

Figure 1. Slump flow measurement.

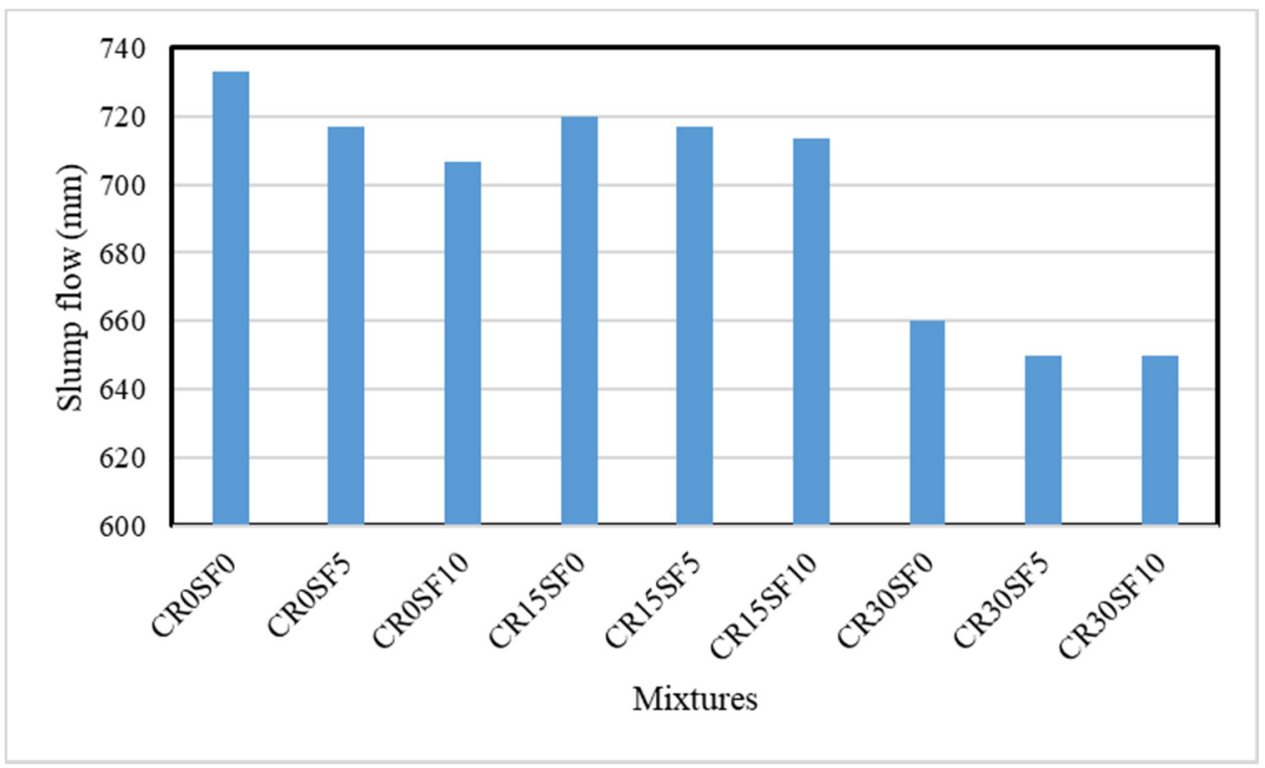

Figure 2. Slump flow of HVFRSCC.

\subsection{Compressive Strength}

The strength development of HVFRSCC from 7 to 28 days curing is shown in Figure 3. The highest compressive strength of the 28-day period, of $66.79 \mathrm{MPa}$, was achieved by CROSF5, having 0\% CR and 5\% SF content. The lowest compressive strength of the 28-day period was achieved by CR30SF5, with the strength of $5.29 \mathrm{MPa}$, having 30\% CR and 5\% SF content. The control mix of HVFA-SCC (CROSF0) possessed a compressive strength of 64.73 MPa during the 28-day period, which is in line with the work of Topçu [35]. It is also notable that by replacing a portion of fine aggregates with $\mathrm{CR}$ will lead to a fall-off in the compressive strength. From Figure 3, the mix with 30\% CR achieved a 5.29 MPa strength only, which shows that the higher amount of $C R$ as a replacer of fine aggregate induces a higher reduction of the compressive strength. This result corresponded well with the experiment by Guneyisi et al. [31], where the results showed a decrease in compressive strength with the increase in rubber content, with and without silica fume. Incorporating CR into SCC increases its porosity. Much void volume is induced during the mixing between CR and cement paste, as CR keeps on repelling water in the process. Besides, the reason causing a reduction in compressive strength regardless of the curing age is the increment of air entrapment volumes, which is caused by the inefficient binding of aggregates and CR. Apart from the air entrapped, the reduction in compressive strength is caused by the interfacial transition zone debility, the poor adhesion between crumb rubber 
and paste matrix, and the low stiffness. Because of the presence of the fine aggregate, and high-surface components such as the SF, HVFRSCC formed pores that allow the water to infiltrate the sample at a higher rate, which reduces the bonding automatically and thus decreases the compressive strength of the specimens [36]. However, the addition of SF can fill in the void present, which then produces a better bonding as well as a decent strength, or at least recovers some of the mechanical strength lost. For instance, CR30SF5 achieved a slight increase in compressive strength from 14 days to 28 days compared to CR30SF10 after doubling the amount of SF. It is deduced that SF has little influence on the compressive strength of HVFRSCC. The beneficial effect of SF is more evident at a lower CR percentage.

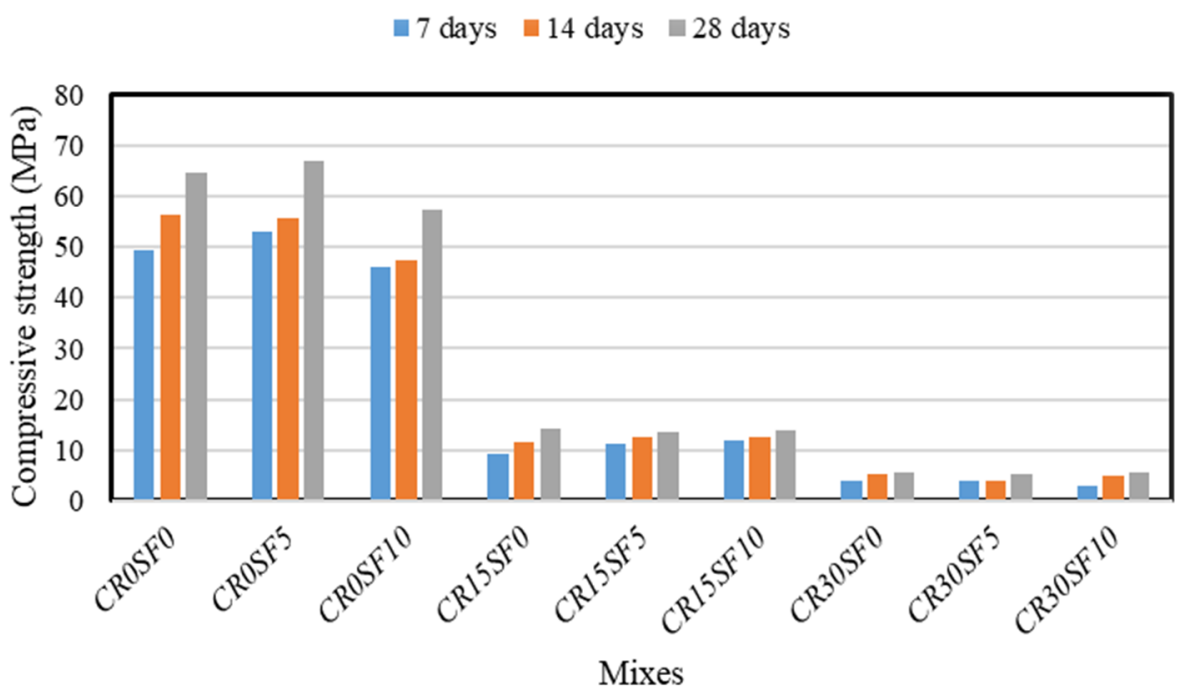

Figure 3. Compressive strength development of HVFRSCC.

As demonstrated in the 2D contour plot in Figure 4, the contour indicates where the red region symbolizes a higher strength region, whereas the blue region indicates the lower strength region of HVFRSCC strength. The higher value for compressive strength is within the red region, followed by the green region, while the lower value for compressive strength is within the blue region. The most optimum compressive strength achieved was $66.79 \mathrm{MPa}$ at $0 \%$ and $5 \%$ for $\mathrm{CR}$ and SF, respectively. The inclined shape taken by the contours indicated that there is a weak interaction between the variables (percentages of CR and SF) $[37,38]$. Based on the 3D response surface plot as shown in Figure 4, the compressive strength significantly decreases with an increase in the content of the CR. Using ANOVA, the relationship between the crumb rubber and SF on the compressive strength of HVFRSCC was represented by the quadratic model shown in Equation (1).

Compressive strength -28 days $(\mathrm{MPa})=65.704-4.8205 \times C R-0.1730 \times S F+0.0242 \times C R \times S F+0.0928 \times C R^{2}-0.0450 \times S F^{2}$

\subsection{Flexural Strength}

The flexural strength of the HVFRSCC is within the range of $0.42 \mathrm{MPa}$ to $1.9 \mathrm{MPa}$, based on the percentage of CR and SF. From Figure 5, the CR0SF10 mix has the highest flexural strength, of 1.9 MPa. Similarly to the compressive strength, the flexural strength decreases significantly with the increase in the percentage of CR. The flexural strength decreases with the incorporation of silica fume and then increases. The incorporation of crumb rubber in the HVFRSCC reduces its flexural strength to almost half of its control mixture [39]. It is worth mentioning that the addition of SF in the HVFRSCC enhances the flexural strength by $8 \%$. This is because of the nature of SF, which slightly improves the concrete strength loss due to crumb rubber addition. The presence of SF particles fills the pores that exist in the C-S-H gel structures whilst behaving as a nucleus to firmly bond 
with C-S-H gel particles. SF has an important pozzolanic reaction of its own. SF particles that act as both filler, which revamps the microstructure of mortar cement, and a medium that promotes the pozzolanic reaction could help enhance the strength development.
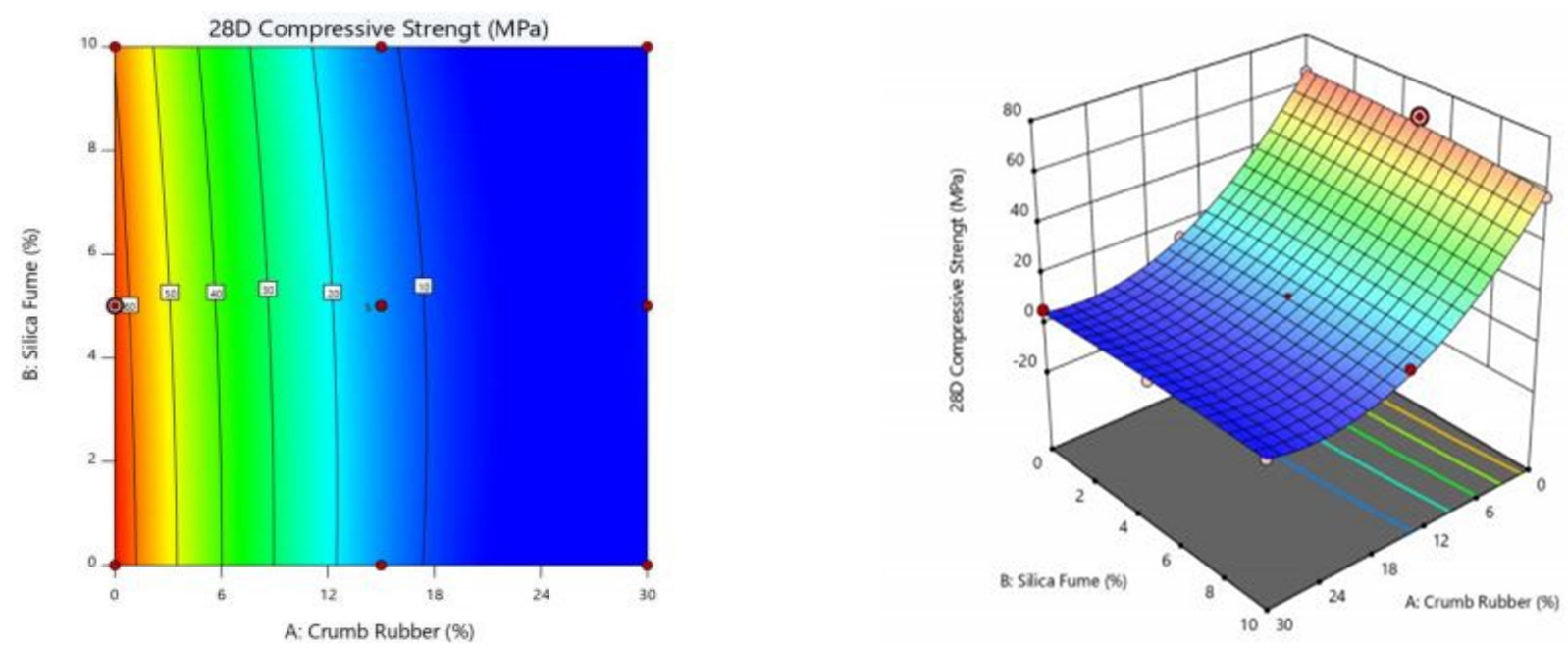

Figure 4. 2D Contour and 3D surface diagram for compressive strength.

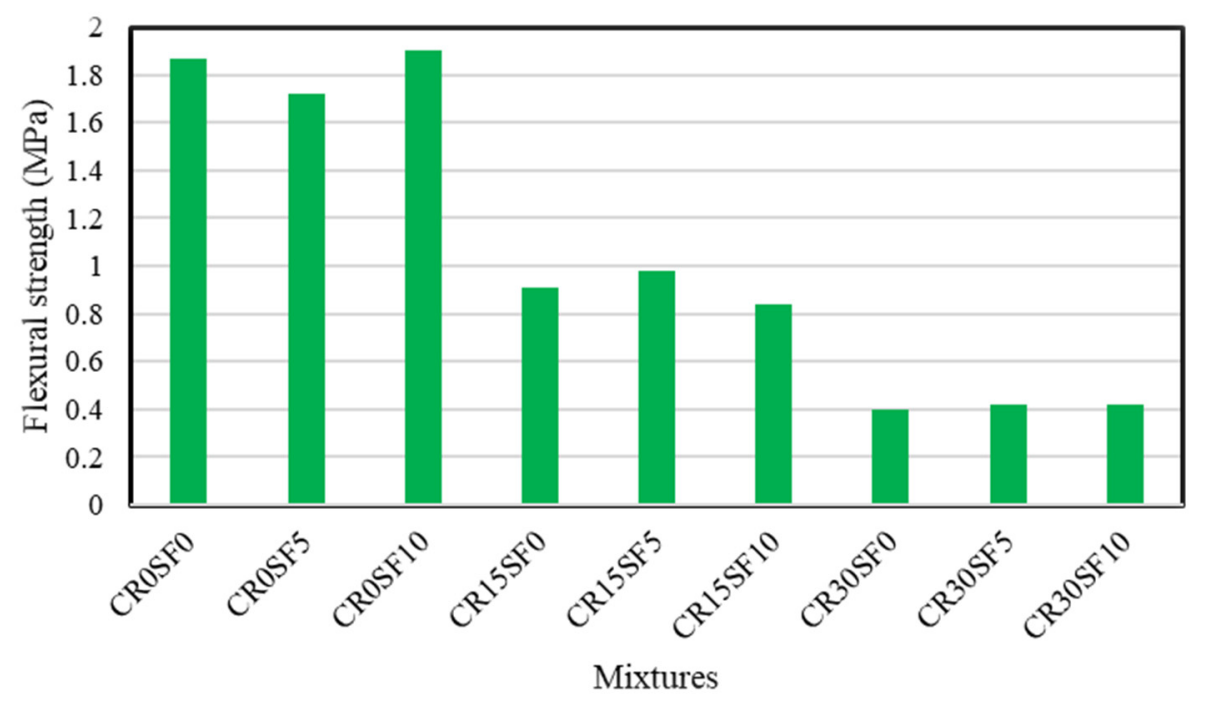

Figure 5. Flexural strength of HVFRSCC at 28 days.

The 2D contour and 3D response surface diagrams generated by RSM for flexural strength are demonstrated in Figure 6. The highest flexural tensile strength, of $1.9 \mathrm{MPa}$, was achieved at $0 \% \mathrm{CR}$ and $10 \% \mathrm{SF}$ content. However, from this model, the slope of the $\mathrm{CR}$ variable is quite steep, indicating that any minor changes in the amount of CR will result in a significant change in flexural tensile strength. By fixing the percentage of $\mathrm{SF}$, an increasing percentage of $\mathrm{CR}$ in the design mix will decrease the flexural tensile strength. This justification can be supported by the straight-line contour plot, where each proportion of the red, green, and blue region is fairly distributed across the map. The model developed from the variable is showed to be satisfactory and significant. Equation (2) indicates HVFRSCC's flexural strength at 28 days. 

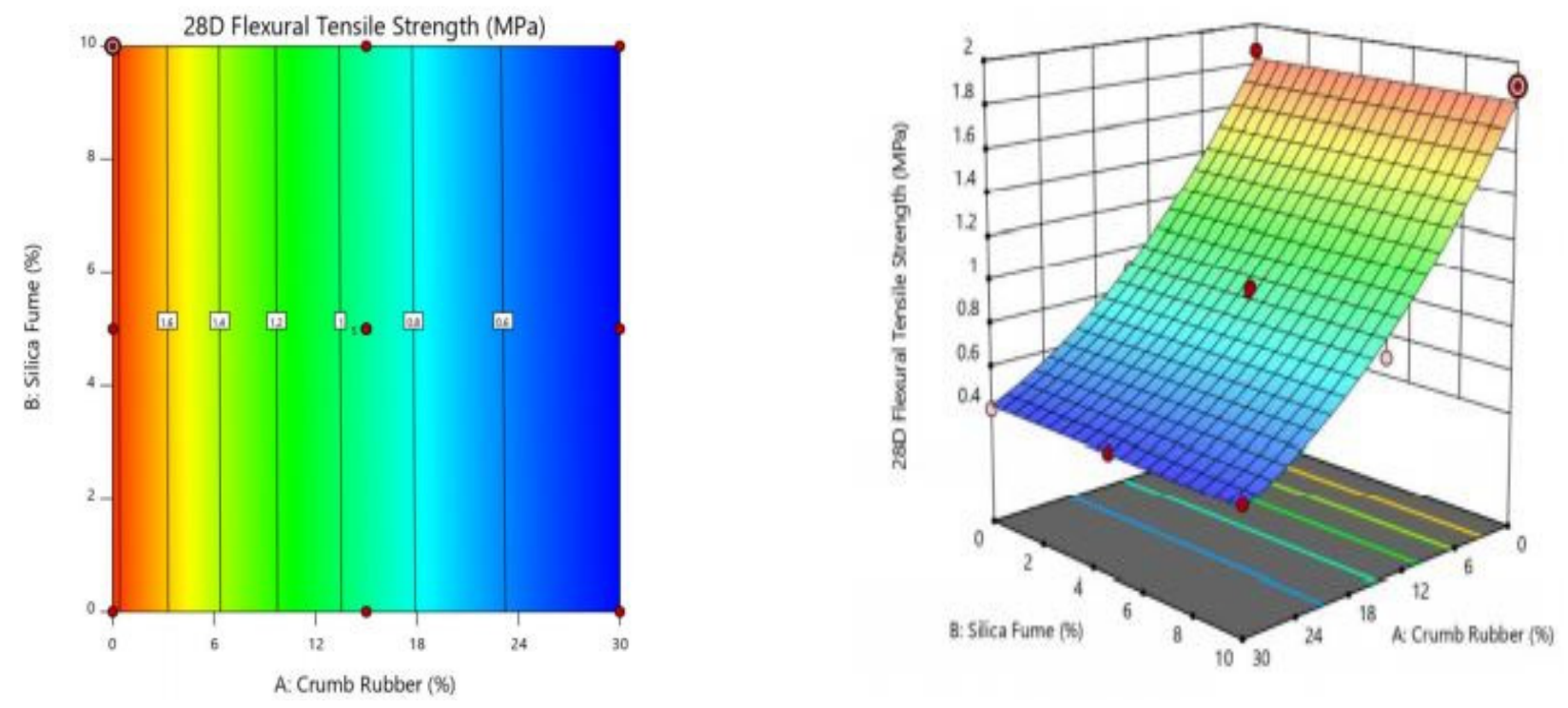

Figure 6. 2D Contour and 3D surface diagram for flexural strength.

\subsection{Splitting Tensile Strength}

The splitting tensile strength of high-volume fly ash rubberized self-compacting concrete (HVFRSCC) at 28 days of curing is shown in Figure 7. The splitting tensile strength of the HVFRSCC is between $0.77 \mathrm{MPa}$ and $5.3 \mathrm{MPa}$, depending on the percentage of CR and SF. The highest split tensile strength of rubberized HVFA SCC was $5.3 \mathrm{MPa}$. It was achieved by taking $0 \% \mathrm{CR}$ and $5 \% \mathrm{SF}$ content. When the percentage of $\mathrm{CR}$ increases up to a certain range, the splitting tensile strength decreases significantly. The control mix sample (CROSF0), which has a splitting tensile strength of $4.19 \mathrm{MPa}$, is quite similar to that of Guneyisi et al. [31]. The addition of 5\% SF in the control mix enhances the splitting tensile strength by $27 \%$, and the splitting tensile strength subsequently decreases by $14 \%$ when the amount of SF reaches $10 \%$. The presence of crumb rubber significantly reduces the splitting tensile of the HVFRSCC to almost half of its control mixture. This significant reduction in the strength of the concrete after the addition of crumb rubber could be attributed to the poor adhesion of scrap tyre particles to the cement paste and a weak interaction with aggregates. Entrapped air on the crumb rubber surface makes the interfacial transition zone (ITZ) thicker than before, and this causes a weak bonding with the cement matrix, as the ITZ is a weak porous zone between cement paste and aggregate [18]. It was observed from Figure 7 that SF can mitigate the mechanical strength loss heavily induced by CR. However, after the SF exceeded the percentage of $5 \%$, with a constant CR percentage, the splitting tensile strength became lower. Irrespective of the comparatively low splitting tensile strength of the HVFRSCC mixtures, rubberized specimens do remain intact after failure, unlike those which do not possess any CR content. This is due to the elongation of the ductile crumb rubber particles and their capability to bridge cracks in specimens, hence inhibiting a complete breakdown.

Based on the 2D contour plot and 3D response surface plot as demonstrated in Figure 8, the highest splitting tensile strength, of $5.3 \mathrm{MPa}$, can be achieved at the percentage of $0 \%$ and $5 \%$ for CR and SF, respectively. The trend of changes induced by both CR and SF is like the compressive strength test. It is deduced from the observation that the model built from the parameters is satisfactory and appropriate. The semi-elliptical lines in the contour diagram shown in Figure 8 indicate that there is a fair relationship between the crumb rubber and silica fume on the splitting tensile strength model. As demonstrated in the $3 \mathrm{D}$ surface diagram, the splitting tensile strength decreased with the increase of crumb rubber. Equation (3) represents the final equation in terms of actual factors for splitting tensile strength. 


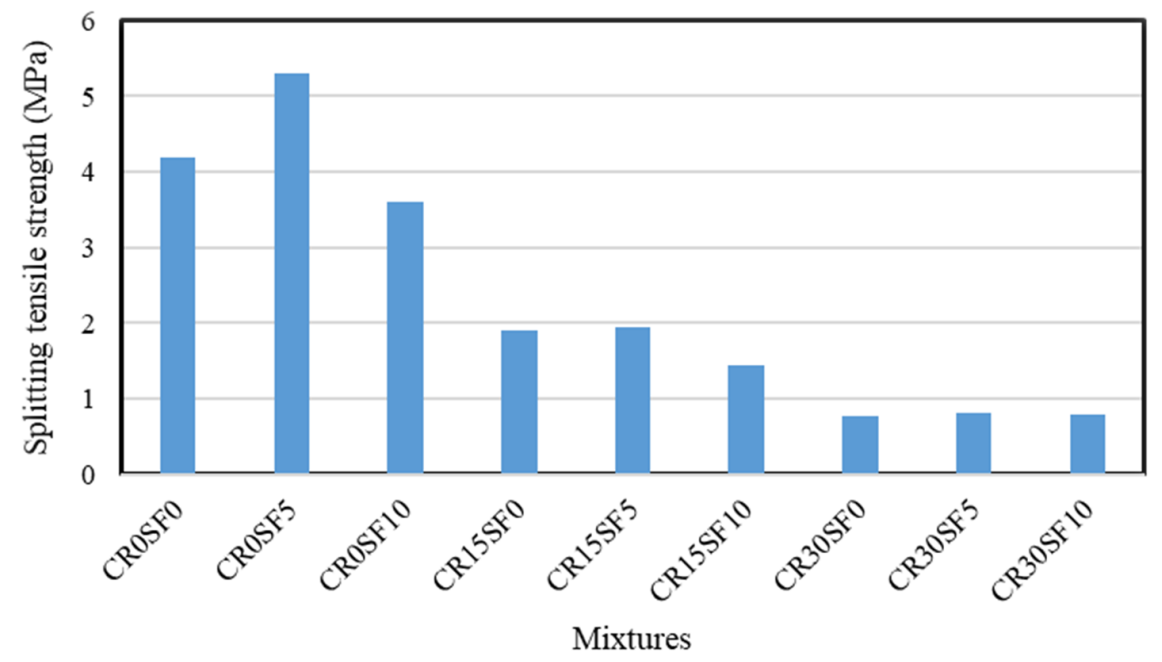

Figure 7. Twenty-eight-day Splitting tensile strength of HVFRSCC.
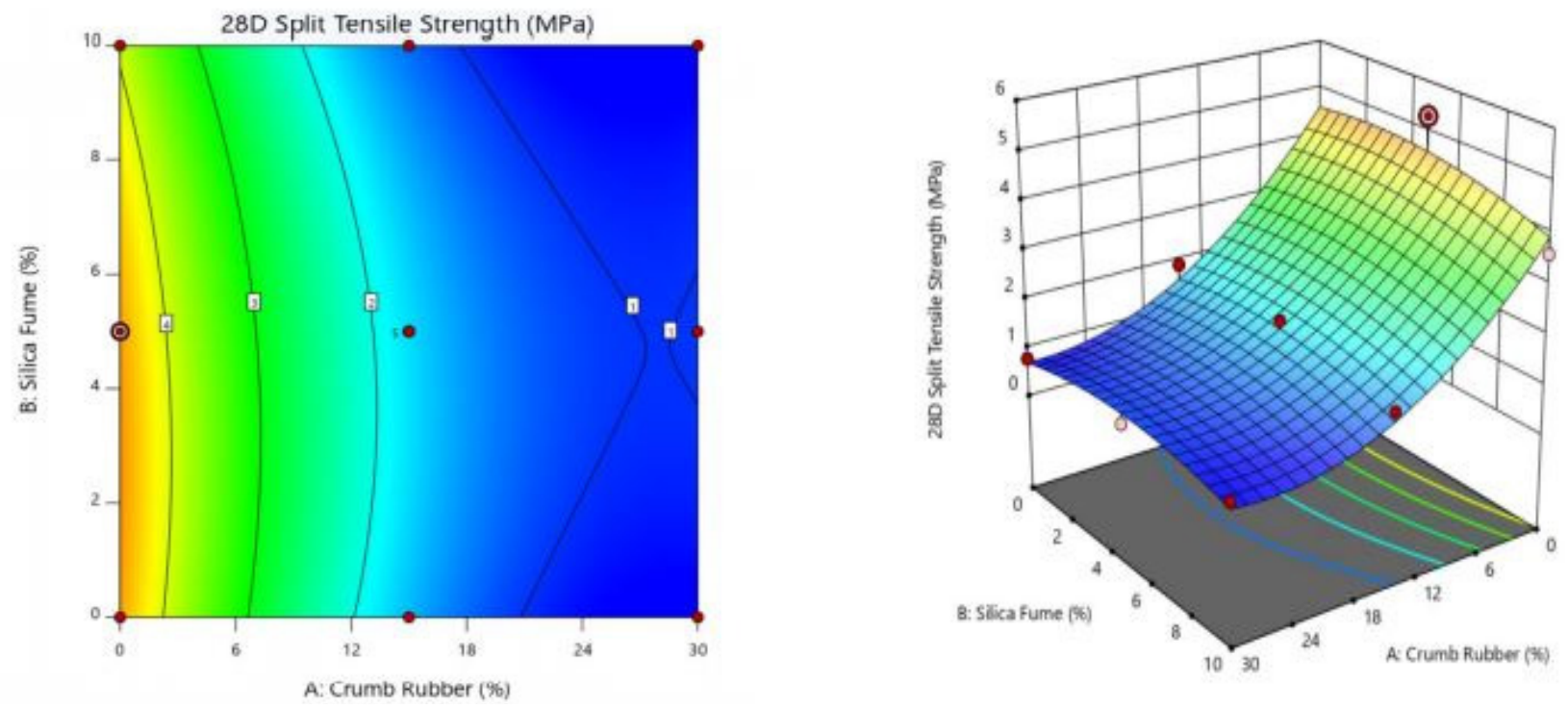

Figure 8. 2D Contour and 3D surface diagram of the splitting tensile strength of HVFRSCC.

\section{Anova Analysis}

Compressive strength, flexural strength, and splitting tensile strength were examined with the effect of the combination of two independent variables, namely, percentage of CR (A) and percentage of SF (B). The significance of the model was determined by an analysis of variance (ANOVA). As shown in Table 3, the F-value for the model of compressive strength is 385.92, for flexural strength is 139.54, and for splitting tensile strength is 5.45, where a high F-value indicates the significance and adequacy of the model. These values show that all the models are significant. The probability that noise would affect "Model F-value" is $0.01 \%$. The $p$-value is less than 0.05 , which indicates that the model is significant. The terms in the compressive strength, flexural, and splitting tensile strength models including $\mathrm{A}-\mathrm{CR}$ and $\mathrm{A}^{2}$ are significant to the models, while model terms $\mathrm{AB}, \mathrm{B}$, and $\mathrm{B}^{2}$ were insignificant for all the output responses. The lack of fit F-values of 0.0007, 0.0267, and 0.0011 shows that all the strength models are significant with respect to lack of fit. Table 4 
shows the validation of the models of compressive strength, flexural strength, and direct tensile strength. The coefficient of determination, which is also known as R-Squared $\left(R^{2}\right)$ for the model should exceed 0.90 to show a high reliability for the equation. The variance among the adjusted $R^{2}$ and predicted $R^{2}$ is less than 0.2 , which means the predicted $R^{2}$ is reasonably in agreement with the adjusted $\mathrm{R}^{2}$. Besides, the minimum requirement for the Adequate (Adeq) precision, which is the measurement of the signal to noise ratio, is 4 [38]. Thus, Adeq Precision for compressive strength, flexural strength, and splitting tensile strength models were $49.643,31.308$, and 19.291, respectively. This shows that all the models can be used to navigate the design space.

Table 3. ANOVA analysis of the response models.

\begin{tabular}{|c|c|c|c|c|c|c|c|}
\hline Models & Source & $\begin{array}{l}\text { Sum of } \\
\text { Squares }\end{array}$ & df & Mean Square & F-Value & $p$-Value & Significance \\
\hline \multirow{7}{*}{$\begin{array}{l}\text { Compressive } \\
\text { Strength }\end{array}$} & Model & 6332.81 & 5 & 1266.56 & 385.92 & $<0.0001$ & Significant \\
\hline & A-CR & 4954.78 & 1 & 4954.78 & 1509.73 & $<0.0001$ & Significant \\
\hline & B-SF & 10.19 & 1 & 10.19 & 3.11 & 0.1214 & insignificant \\
\hline & $\mathrm{AB}$ & 13.14 & 1 & 13.14 & 4.00 & 0.0855 & insignificant \\
\hline & $A^{2}$ & 1204.05 & 1 & 1204.05 & 366.87 & $<0.0001$ & Significant \\
\hline & $\mathrm{B}^{2}$ & 3.50 & 1 & 3.50 & 1.07 & 0.3362 & insignificant \\
\hline & Lack of Fit & 22.54 & 3 & 7.51 & 68.60 & 0.0007 & Significant \\
\hline \multirow{7}{*}{$\begin{array}{l}\text { Flexural } \\
\text { Strength }\end{array}$} & Model & 3.13 & 5 & 0.63 & 139.54 & $<0.0001$ & Significant \\
\hline & $\mathrm{A}-\mathrm{CR}$ & 3.00 & 1 & 3.00 & 670.05 & $<0.0001$ & Significant \\
\hline & B-SF & $1.215 \times 10^{-4}$ & 1 & $1.215 \times 10^{-4}$ & 0.027 & 0.8739 & insignificant \\
\hline & $\mathrm{AB}$ & $2.500 \times 10^{-5}$ & 1 & $2.500 \times 10^{-5}$ & $5.578 \times 10^{-3}$ & 0.9426 & insignificant \\
\hline & $\mathrm{A}^{2}$ & 0.11 & 1 & 0.11 & 23.75 & 0.0018 & Significant \\
\hline & $\mathrm{B}^{2}$ & $7.725 \times 10^{-6}$ & 1 & $7.725 \times 10^{-6}$ & $1.723 \times 10^{-3}$ & 0.9680 & insignificant \\
\hline & Lack of Fit & 0.028 & 3 & $9.184 \times 10^{-3}$ & 9.61 & 0.0267 & significant \\
\hline \multirow{6}{*}{$\begin{array}{l}\text { Splitting } \\
\text { Tensile } \\
\text { Strength }\end{array}$} & Model & 21.78 & 4 & 5.45 & 44.70 & $<0.0001$ & Significant \\
\hline & A-CR & 19.13 & 1 & 19.13 & 157.03 & $<0.0001$ & Significant \\
\hline & B-SF & 0.17 & 1 & 0.17 & 1.43 & 0.2664 & insignificant \\
\hline & $\mathrm{A}^{2}$ & 2.46 & 1 & 2.46 & 20.18 & 0.0020 & significant \\
\hline & $B^{2}$ & 0.52 & 1 & 0.52 & 4.28 & 0.0724 & insignificant \\
\hline & Lack of Fit & 0.96 & 4 & 0.24 & 51.25 & 0.0011 & significant \\
\hline
\end{tabular}

Table 4. Models' validation.

\begin{tabular}{cccc}
\hline Model Terms & Compressive Strength & Flexural Strength & Splitting Tensile Strength \\
\hline Std. Dev. & 1.81 & 0.067 & 0.35 \\
Mean & 23.21 & 1.02 & 2.16 \\
C.V. $\%$ & 7.80 & 6.59 & 16.17 \\
$\mathrm{R}^{2}$ & 0.9964 & 0.9901 & 0.9572 \\
Adj. $\mathrm{R}^{2}$ & 0.9938 & 0.9830 & 0.9358 \\
Pred. $\mathrm{R}^{2}$ & 0.9673 & 0.9251 & 0.8250 \\
Adeq. precision & 49.643 & 31.308 & 19.291 \\
\hline
\end{tabular}

The graph of Normal Plot of Residuals is one of the methods used to validate the models, while the graph of Normal Plot of Residuals is a straight line. Hence, the forecasted values will provide more precise results than expected when all the points roughly fall on the normality line [40,41]. Normal Plot of Residuals is used to identify the appropriateness of the model, and the ability of the model to determine the optimal extraction parameters based on the response results. The graph of Normal Plot of Residuals for all the responses is shown in Figure 9. 


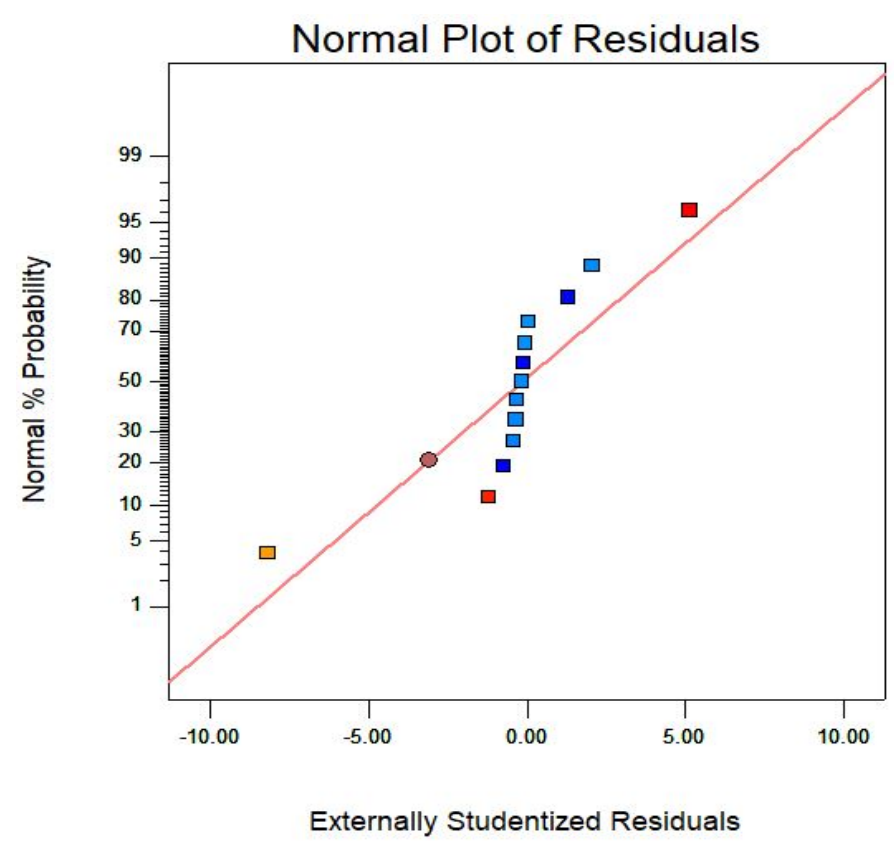

Figure 9. Normal plot of residuals.

Optimization and Experimental Validation

The response surface method (RSM) was used to model the effect of two variables in this study, which are the silica fume and crumb rubber, and their interactions with the mechanical strength properties. As mentioned above, once all the findings have been effectively obtained from the initial mixing, based on the 13 various mix designs conjured by the initial RSM mix design, they were inputted into the RSM once more to obtain a finalized model which is to be tested for its validity. The verification mix designs were acquired via a multi response optimization technique. In this response, the target was to maximize the response, which is the mechanical strength, and four solutions came up. The solution of the highest desirability is selected. The equation obtained from the RSM was validated experimentally. A total of four solutions developed from DOE to validate the equation are shown in Table 5, below, which shows the summary of the optimization mix. Figure 10 shows the optimization ramp with the desirability function. The desirability equals 0.609 , which means that with $1.85 \%$ of $C R$ and $7.4 \%$ of SF, the percentage for achieving 53.688 $\mathrm{MPa}$ for compressive strength, $1.69 \mathrm{MPa}$ for flexural strength, and $3.903 \mathrm{MPa}$ for split tensile strength is $60.9 \%$.

Table 5. Summary of Optimization Mix.

\begin{tabular}{ccccccc}
\hline No. of Run & CR (\%) & SF (\%) & $\begin{array}{c}\text { Compressive } \\
\text { Strength (MPa) }\end{array}$ & $\begin{array}{c}\text { Flexural Strength } \\
\mathbf{( M P a )}\end{array}$ & $\begin{array}{c}\text { Splitting Tensile } \\
\text { Strength (MPa) }\end{array}$ & $\begin{array}{c}\text { Desirability } \\
\text { (MPa) }\end{array}$ \\
\hline 1 & 1.850 & 7.401 & 53.688 & 1.695 & 3.903 & 0.609 \\
2 & 1.847 & 7.419 & 53.686 & 1.695 & 3.901 & 0.609 \\
3 & 1.854 & 7.362 & 53.701 & 1.694 & 0.609 & 0.046 \\
4 & 29.895 & 5.223 & 6.170 & 0.415 & 1.015 \\
\hline
\end{tabular}



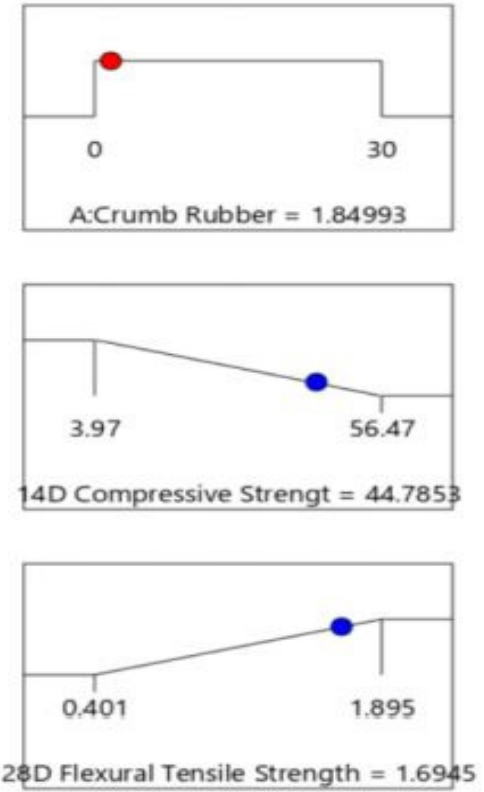
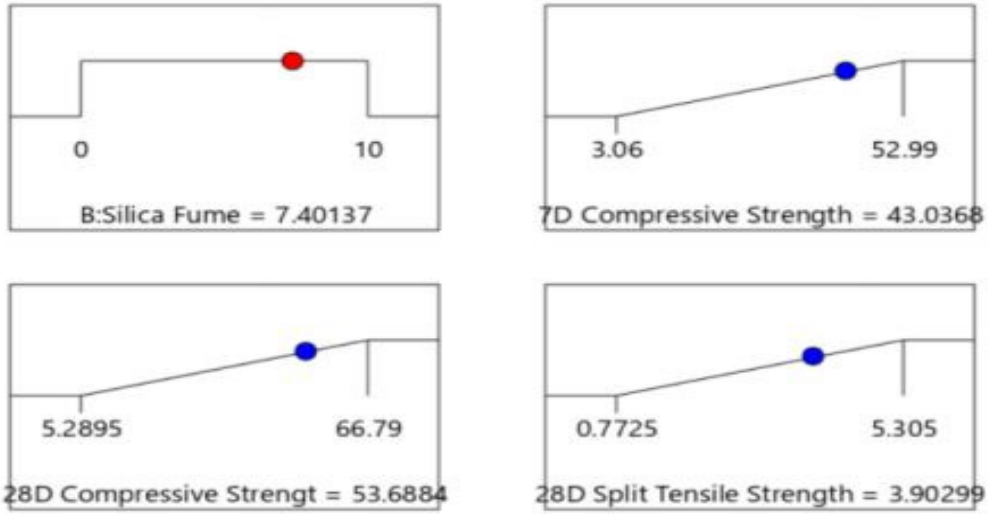

Desirability $=0.609$

Solution 1 out of 4

Figure 10. Optimization ramp showing the predicted results.

\section{Conclusions}

It was observed that crumb rubber in high volumes might not enable SCC composites to meet their strength requirement for any structural use. The incorporation of crumb rubber into concrete mixes is undeniably an eco-friendly move, but any reduction in mechanical strength can be disastrous for structural usage, and hence should not be used in structural elements that require a high strength. However, rubberized self-compacting concrete can be used in other areas, such as slab work, flooring, parking and driveways, compound construction, etc. The findings show that the addition of SF slightly enhances the mechanical strength of high-volume fly ash rubberized self-compacting concrete. SF improves the SCC strength loss due to CR by acting as both a filler that revamps the microstructure of mortar cement and a medium that promotes pozzolanic reaction. Mixtures with a higher quantity of $\mathrm{CR}$ experienced a drop in all the mechanical strength properties, especially design mixes which utilize $30 \% \mathrm{CR}$ replacement. The lowest 28 -day compressive strength of $5.29 \mathrm{MPa}$ was achieved when $30 \%$ of CR and 5\% of SF were utilized. Moreover, model equations were successfully established to predict the compressive, flexural strength, and splitting tensile strength of HVFRSCC, and the optimization was successfully carried out.

Author Contributions: Conceptualization, B.A.T., W.R. and S.A.; methodology, M.A.M., S.H. and K.L.; software, S.H. and K.L.; validation, S.A.; formal analysis, B.A.T. and W.R.; investigation, M.A.M., S.H. and K.L.; resources, W.S.A.; data curation, K.L., B.A.T. and S.A.; writing-original draft preparation, M.A.M., S.H., K.L., W.R. and S.A.; writing-review and editing, W.S.A., M.A.M. and B.A.T.; supervision, W.S.A.; project administration, W.S.A. All authors have read and agreed to the published version of the manuscript.

Funding: Not applicable.

Institutional Review Board Statement: Not applicable.

Informed Consent Statement: Not applicable.

Data Availability Statement: All the data are available within this manuscript.

Acknowledgments: The authors would like to appreciate the YUTP-PRF project (cost center \# 015LC0-088) awarded to Wesam Alaloul for the support.

Conflicts of Interest: The authors declare no conflict of interest. 


\section{References}

1. Kamal, M.M.; Safan Mohamed, A.; Etman Zeinab, A.; Kasem Bsma, M. Mechanical properties of self-compacted fiber concrete mixes. HBRC J. 2014, 10, 25-34. [CrossRef]

2. Ramkumar, K.B.; Rajkumar, P.K.; Ahmmad, S.N.; Jegan, M. A Review on Performance of Self-Compacting Concrete-Use of Mineral Admixtures and Steel Fibres with Artificial Neural Network Application. Constr. Build. Mater. 2020, $261,120215$. [CrossRef]

3. Petit, J.Y.; Wirquin, E.; Duthoit, B. Influence of temperature on yield value of highly flowable micromortars made with sulfonatebased superplasticizers. Cem. Concr. Res. 2005, 35, 256-266. [CrossRef]

4. Musarrat, M.A.; Ullah, S.; Khan, S.H.; Ullah, K. Effect of bentonite on fresh and hardened property of self compacting concrete. Sarhad Univ. Int. J. Basic Appl. Sci. 2017, 4, 54-61.

5. Lussy, C.L.; Sugiarto, H. Pengaruh Penggunaan Polypropylene Fibre Terhadap Karakteristik Self Compacting Concrete. J. Dimens. Pratama Tek. Sipil 2020, 9, 49-55.

6. Mansour, S.M. Behavior of self-compacting concrete incorporating calcined pyrophyllite as supplementary cementitious material. J. Build. Mater. Struct. 2020, 7, 119-129.

7. Kumar, K.R.; Shyamala, G.; Awoyera, P.O.; Vedhasakthi, K.; Olalusi, O.B. Cleaner production of self-compacting concrete with selected industrial rejects-an overview. Silicon 2020, 1-12. [CrossRef]

8. de Matos, P.R.; Oliveira, J.C.; Medina, T.M.; Magalhães, D.C.; Gleize, P.J.; Schankoski, R.A.; Pilar, R. Use of air-cooled blast furnace slag as supplementary cementitious material for self-compacting concrete production. Constr. Build. Mater. 2020, $262,120102$. [CrossRef]

9. Mohammed, B.S.; Yen, L.Y.; Haruna, S.; Huat, M.L.S.; Abdulkadir, I.; Al-Fakih, A.; Liew, M.S.; Zawawi, N.A.W.A. Effect of Elevated Temperature on the Compressive Strength and Durability Properties of Crumb Rubber Engineered Cementitious Composite. Materials 2020, 13, 3516. [CrossRef] [PubMed]

10. Valizadeh, A.; Hamidi, F.; Aslani, F.; Shaikh, F.U.A. The effect of specimen geometry on the compressive and tensile strengths of self-compacting rubberised concrete containing waste rubber granules. Structures 2020, 27, 1646-1659. [CrossRef]

11. Shaaban, I.G.; Rizzuto, J.P.; El-Nemr, A.; Bohan, L.; Ahmed, H.; Tindyebwa, H. Mechanical properties and air permeability of concrete containing waste tyres extracts. J. Mater. Civ. Eng. 2021, 33, 04020472. [CrossRef]

12. Sofi, A. Effect of waste tyre rubber on mechanical and durability properties of concrete-A review. Ain Shams Eng. J. 2018, 9, 2691-2700. [CrossRef]

13. Ismail, M.K.; Hassan, A.A.A. Use of Steel Fibers to Optimize Self-Consolidating Concrete Mixtures Containing Crumb Rubber. ACI Mater. J. 2017, 114, 581-594. [CrossRef]

14. Zhu, H.; Duan, F.; Shao, J.-W.; Shi, W.; Lin, Z. Material and durability study of a 10-year-old crumb rubber concrete bridge deck in Tianjin, China. Mag. Concr. Res. 2021, 73, 499-511. [CrossRef]

15. Strukar, K.; Šipoš, T.K.; Miličević, I.; Bušić, R. Potential use of rubber as aggregate in structural reinforced concrete elementA review. Eng. Struct. 2019, 188, 452-468. [CrossRef]

16. Alaloul, W.S.; Musarat, M.A.; A Tayeh, B.; Sivalingam, S.; Bin Rosli, M.F.; Haruna, S.; Khan, M.I. Mechanical and deformation properties of rubberized engineered cementitious composite (ECC). Case Stud. Constr. Mater. 2020, 13, e00385. [CrossRef]

17. Mohammed, B.S.; Hossain, K.M.A.; Swee, J.T.E.; Wong, G.; Abdullahi, M. Properties of crumb rubber hollow concrete block. J. Clean. Prod. 2012, 23, 57-67. [CrossRef]

18. Mohammed, B.S.; Adamu, M. Mechanical performance of roller compacted concrete pavement containing crumb rubber and nano silica. Constr. Build. Mater. 2018, 159, 234-251. [CrossRef]

19. Tjaronge, M.W.; Musarat, M.A.; Law, K.; Alaloul, W.S.; Ayub, S. Effect of Graphene Oxide on Mechanical Properties of Rubberized Concrete: A Review. In Proceedings of the Lecture Notes in Civil Engineering, Kuching, Malaysia, 13-15 June 2021; Springer Science and Business Media LLC: Singapore, 2021; pp. 484-492.

20. Alaloul, W.S.; Musarat, M.A.; Hui, C.J. Impact of Elevated Temperature on Rubberized Concrete: A Review. In Proceedings of the Lecture Notes in Civil Engineering, Kuching, Malaysia, 13-15 June 2021; Springer Science and Business Media LLC: Singapore, 2021; pp. 421-427.

21. Amat, R.C.; Ismail, K.N.; Ahmad, K.R.; Ibrahim, N.M. Effects of Metakoalin on Municipal Solid Waste Incineration (MSWI) Bottom Ash-Cement Composite. Mater. Sci. Forum 2020, 1010, 653-658. [CrossRef]

22. Kumar, M.; Sinha, A.K.; Kujur, J. Mechanical and durability studies on high-volume fly-ash concrete. Struct. Concr. 2021, 22, E1036-E1049. [CrossRef]

23. Niwas, R.; Mathur, D.; Agarwal, S. A Study to Use of Waste Material in Bituminous Concrete (BC); IJTIMES: Mumbai, India, 2019.

24. Sandanayake, M.; Gunasekara, C.; Law, D.; Zhang, G.; Setunge, S.; Wanijuru, D. Sustainable criterion selection framework for green building materials-An optimisation based study of fly-ash Geopolymer concrete. Sustain. Mater. Technol. 2020, 25 , e00178. [CrossRef]

25. Ibrahim, O.M.O.; Tayeh, B.A. Combined effect of lightweight fine aggregate and micro rubber ash on the properties of cement mortar. Adv. Concr. Constr. 2020, 10, 537-546.

26. Çakır, Ö. Experimental analysis of properties of recycled coarse aggregate (RCA) concrete with mineral additives. Constr. Build. Mater. 2014, 68, 17-25. [CrossRef] 
27. Nili, M.; Afroughsabet, V. Combined effect of silica fume and steel fibers on the impact resistance and mechanical properties of concrete. Int. J. Impact Eng. 2010, 37, 879-886. [CrossRef]

28. Siddique, R. Utilization of silica fume in concrete: Review of hardened properties. Resour. Conserv. Recycl. 2011, 55, 923-932. [CrossRef]

29. Xie, J.; Fang, C.; Lu, Z.; Li, Z.; Li, L. Effects of the addition of silica fume and rubber particles on the compressive behaviour of recycled aggregate concrete with steel fibres. J. Clean. Prod. 2018, 197, 656-667. [CrossRef]

30. Onuaguluchi, O.; Panesar, D.K. Hardened properties of concrete mixtures containing pre-coated crumb rubber and silica fume. J. Clean. Prod. 2014, 82, 125-131. [CrossRef]

31. Güneyisi, E.; Gesoğlu, M.; Özturan, T. Properties of rubberized concretes containing silica fume. Cem. Concr. Res. 2004, 34, 2309-2317. [CrossRef]

32. Mohammed, B.S.; Khed, V.C.; Nuruddin, M.F. Rubbercrete mixture optimization using response surface methodology. J. Clean. Prod. 2018, 171, 1605-1621. [CrossRef]

33. C293/C293M-16, A. Standard Test Method for Flexural Strength of Concrete (Using Simple Beam with Center-Point Loading); ASTM International: West Conshohocken, PA, USA, 2016.

34. European Federation for Specialist Construction Chemicals and Concrete Systems. Guidelines for Self-Compacting Concrete, English ed.; European Federation for Specialist Construction Chemicals and Concrete Systems: Norfolk, UK, February 2002.

35. Topçu, I.B.; Bilir, T. Experimental investigation of some fresh and hardened properties of rubberized self-compacting concrete. Mater. Des. 2009, 30, 3056-3065. [CrossRef]

36. Wang, X.; Subramaniam, K.V. Ultrasonic monitoring of capillary porosity and elastic properties in hydrating cement paste. Cem. Concr. Compos. 2011, 33, 389-401. [CrossRef]

37. Mohammed, B.S.; Xian, L.W.; Haruna, S.; Liew, M.S.; Abdulkadir, I.; Zawawi, N.A.W.A. Deformation Properties of Rubberized Engineered Cementitious Composites Using Response Surface Methodology. Iran. J. Sci. Technol. Trans. Civ. Eng. 2020, 1-12. [CrossRef]

38. Mohammed, B.S.; Haruna, S.; Wahab, M.M.B.A.; Liew, M. Optimization and characterization of cast in-situ alkali-activated pastes by response surface methodology. Constr. Build. Mater. 2019, 225, 776-787. [CrossRef]

39. Ganesan, N.; Raj, J.B.; Shashikala, A. Flexural fatigue behavior of self compacting rubberized concrete. Constr. Build. Mater. 2013, 44, 7-14. [CrossRef]

40. Khed, V.C.; Mohammed, B.S.; Nuruddin, M.F. Effects of different crumb rubber sizes on the flowability and compressive strength of hybrid fibre reinforced ECC. In IOP Conference Series: Earth and Environmental Science; IOP Publishing: Bristol, UK, 2018.

41. Haruna, S.; Mohammed, B.S.; Wahab, M.M.A.; Al-Fakih, A. Compressive strength and workability of High Calcium One-Part alkali activated mortars using response surface methodology. In IOP Conference Series: Earth and Environmental Science 2nd International Conference on Civil and Environmental Engineering; IOP Science: Langkawi, Malaysia, 2020. 